\title{
Efficiency of co-feeding red porgy (Pagrus pagrus L.) larvae with live and compound diet
}

\author{
Eficiencia de la alimentación mixta con dieta viva y alimento balanceado en \\ larvas de besugo (Pagrus pagrus L.) \\ Eddie O. Aristizábal ${ }^{1}$ and Julieta Suárez ${ }^{1,2}$ \\ ${ }^{1}$ Instituto Nacional de Investigación y Desarrollo Pesquero (INIDEP). Paseo V. Ocampo \#1, Escollera Norte, B7602HSA, \\ Mar del Plata, Argentina \\ ${ }^{2}$ Consejo Nacional de Investigaciones Científicas y Técnicas (CONICET). Av. Rivadavia 1917, C1033AAJ, Buenos Aires, Argentina \\ eddie@inidep.edu.ar
}

Resumen.- El besugo (Pagrus pagrus) es una importante especie comercial y deportiva con buenas perspectivas para acuicultura. Debido a que importantes mortalidades han dificultado la producción masiva de esta especie, en este trabajo se describen tres ensayos de destete para investigar sus efectos sobre la supervivencia y el crecimiento de las larvas de besugo nacidas en el laboratorio: A) destete tradicional de tres pasos (rotíferos - Artemia - dieta) (control); B) destete temprano con alimentación mixta en un paso (rotíferos Artemia + dieta) y C) destete temprano directo de un paso (rotíferos - dieta). Se registraron diferencias significativas entre los tres tratamientos $(P<0,05)$. Las mejores tasas de supervivencia $(45,6 \pm 7,6 \%)$ y crecimiento larval $(7,4 \pm 0,5$ $\mathrm{mm}$ ) se encontraron en el tratamiento B. Los resultados indican que la alimentación simultánea de las larvas de besugo con dieta viva e inerte a partir del día 20 después de la eclosión es una prometedora estrategia de destete para la cría de esta especie.

Palabras clave: Crecimiento, desarrollo larval, destete

\begin{abstract}
The red porgy (Pagrus pagrus) is an important commercial and recreational species with very good prospect for aquaculture. Because significant mortalities, the mass production of this species is limited. This paper describes three weaning strategies to investigate their effects on the survival and growth of red porgy larvae reared in laboratory: A) traditional three-step weaning (rotifers - Artemia - diet) (control); B) one-step early weaning by co-feeding (rotifers Artemia + diet), and C) one-step direct early weaning (rotifers - diet). Sigificative differences were recorded among treatments $(P<0.05)$. Best survival rate $(45.6 \pm 7.6 \%)$ and growth $(7.4 \pm 0.5 \mathrm{~mm})$ were found in treatment $B$. Results indicate that co-feeding red porgy larvae with inert and live diets from day 20 after hatching is a promising weaning strategy in the hatchery of this species.
\end{abstract}

Key words: Growth, larval development, weaning

\section{Introduction}

The red porgy (Pagrus pagrus) is an important commercial and recreational species found in the Argentinean waters (Cotrina \& Cousseau 1977, Cotrina 1989), with very good prospect for aquaculture due to its suitability for reproduction in captivity (Mylonas et al. 2003, Aristizábal in press). For this reason, the red porgy is intensively studied as a potential aquaculture candidate at the National Fisheries Research and Development Institute (INIDEP) since 2000, with the support of the Overseas Fisheries Cooperation Foundation (OFCF) of Japan.
Red porgy larvae, like other marine fish larvae, are characterized by small size and early stage of development at hatching, being very vulnerable to the rearing conditions and demanding live prey during that period (Sargent et al. 1997). Any kind of diet or rearing method that may reduce the production of live feed will be of great technical and economical interest. Fernández-Díaz et al. (1994) found that gilthead seabream (Sparus aurata) larvae previously fed live feeds would preferentially select live feed during cofeeding with inert feed. Co-feeding may improve larval nutrition and may condition the larvae to more readily accept the manufactured diet when live feeds are withdrawn (Munilla-Moran et al. 1990, Person le Ruyet 
et al. 1993, Rosenlund et al. 1997, Cañavate \& Fernández-Díaz 1999). The quality and quantity of both live and manufactured diets are also of considerable importance for growth, survival and success during weaning (Bromley \& Howell 1983, Person le Ruyet et al. 1993).

Red porgy larvae are normally fed Artemia nauplii from day 20-22 after hatching (AH), rotifers density gradually decreases from that time on (Stephanou et al. 1995, Roo et al. 1999, Mihelakakis et al. 2001), while weaning usually starts after day $30 \mathrm{AH}$ (Mihelakakis et al. 2001). Because significant problems have prevented the mass production of this species (Conides \& Glamuzina 2001, Hernández-Cruz et al. 1999), we considered the possibility of an early weaning based on both a good osteological-cartilaginous development of the mouth of red porgy larvae by day $20 \mathrm{AH}$ (Aristizábal 2003), and also the presence of the necessary enzymes for digestion in related species, like the red seabream Pagrus major (Kanazawa et al. 1989) and the gilthead seabream Sparus aurata (Kolkovski 2001), at early stages of development. This report details a successful attempt to increase survival rate at larval rearing of $P$. pagrus.

\section{Materials and methods}

\section{Larvae supply}

Red porgy ( $P$. pagrus) eggs were collected from spontaneous spawnings from a broodstock kept under a recirculation system at the National Fisheries Research and Development Institute (INIDEP), Argentina. Eggs were incubated at $19.5 \pm 0.5^{\circ} \mathrm{C}$ in 200 - $\mathrm{L}$ cylindricalshaped nets inside a 2000-L recirculated tank with gentle aeration. Newly hatched larvae were used to seed nine $0.4 \mathrm{~m}^{3}$ circular fiberglass tanks at a density of 3040 larvae/ $\mathrm{L}^{-1}$.

Table 1

Description of the feeding regimes during the larval rearing of $P$. pagrus

Descripción del régimen alimenticio durante la cría larval de $P$. pagrus

\begin{tabular}{|c|c|c|c|c|}
\hline Feeding regime (days) & $\begin{array}{c}\text { Algae } \\
\left(\mathrm{x} 10^{6} \text { cells } \mathrm{mL}^{-1}\right)\end{array}$ & $\begin{array}{l}\text { Rotifers } \\
\text { (ind } \mathrm{mL}^{-1} \text { ) }\end{array}$ & $\begin{array}{c}\text { Artemia } \\
\text { (nauplii } \mathrm{mL}^{-1} \text { ) }\end{array}$ & $\begin{array}{c}\text { Dry feed } \\
\left(\mathrm{mg} \mathrm{mL}^{-1}\right)\end{array}$ \\
\hline \multicolumn{5}{|l|}{ A- Traditional (control) } \\
\hline $3-22$ & 0.3 & $10-20$ & - & - \\
\hline $20-25$ & - & - & $1-3$ & - \\
\hline $26-40$ & - & - & $5-10$ & - \\
\hline $35-50$ & - & - & - & 9 \\
\hline \multicolumn{5}{|l|}{ B- One-step early } \\
\hline $3-22$ & 0.3 & $10-20$ & - & - \\
\hline $20-25$ & - & - & $1-10$ & 4 \\
\hline $26-40$ & - & - & - & 10 \\
\hline $35-50$ & - & - & - & 20 \\
\hline \multicolumn{5}{|l|}{ C- One-step direct } \\
\hline $3-22$ & 0.3 & $10-20$ & - & - \\
\hline $20-25$ & - & - & - & 6 \\
\hline $26-40$ & - & - & - & - \\
\hline $35-50$ & - & - & - & - \\
\hline
\end{tabular}




\section{Experimental conditions}

The rearing tanks were kept under a flow-through system with an increasing daily water exchange from $10 \%$ at hatching (day 0 ) to $500 \%$ at day $50 \mathrm{AH}$, accordingly to the age of the larvae. During the period of experimentation, the water temperature was kept at $19.5 \pm 0.5^{\circ} \mathrm{C}$ and the salinity ranged from 33 to $34 \mathrm{psu}$. A skimmer was used to remove surface oil film and other residuals. Deposits from the bottom of the tanks were carefully removed daily from day $15 \mathrm{AH}$. Light intensity and photoperiod were $200 \mathrm{~lx}$ at the water surface (Digital light meter, Cole-Parmer) and 10 D : 14 $\mathrm{L}$, respectively.

In all treatments, green water containing Nannochloropsis oculata was supplied to the rearing tanks every morning to achieve an approximate concentration of $1-3 \times 10^{6}$ cells $/ \mathrm{mL}$. Three experimental feeding designs by triplicate were used (Table 1): A) Traditional three-step weaning (rotifers - Artemia - diet) (control); B) one-step early weaning by co-feeding (rotifers - Artemia + diet), and C) one-step direct early weaning (rotifers - diet). The larvae were initially fed with enriched rotifers (Brachionus sp.) from day $3 \mathrm{AH}$. Rotifer density was maintained at $10-20 / \mathrm{mL}$. Red porgy were fed enriched Artemia nauplii twice a day from day $20 \mathrm{AH}$ at increasing densities from 1 to 10 nauplii/mL. From day $20 \mathrm{AH}$, no new rotifers were added to the rearing tank but their presence was detected until day 23 AH. A commercial artificial feed (Otohime B1, B2, C1 and C2, Nisshin Inc., Japan) was used from day $35 \mathrm{AH}$ in trial A, and from day $20 \mathrm{AH}$ in trials $\mathrm{B}$ and $\mathrm{C}$. Rotifers and Artemia nauplii were enriched with a commercial enrichment media (DHA-Ce, Oriental Ind., Japan) plus $N$. oculata, during 6-14 h.

Larval sampling was performed by dipping the water column at different zones and individually counting the live larvae. Morphological observations and body measurements were carried out in 50 specimens each day at the yolk-sac stage, and every week during the larval and fingerling stage. Larvae were anesthetized by adding a couple of drops of a solution of benzocaine : acetone $(2: 1 \mathrm{w} / \mathrm{v})$ into a $50 \mathrm{~mL}$ beaker.

\section{Data and statistical analysis}

Data are presented as means \pm SD. Means from the different treatments were compared by One-way ANOVA and factorial analysis (Sokal \& Rohlf 1981). When significant differences were detected, Tukey multiple-range procedure was used to determine statistical differences among treatments. A probability level of $P<0.05$ was used to judge whether any effects were significant.

\section{Results}

The hatching period at a water temperature of $19.5 \pm$ $0.5^{\circ} \mathrm{C}$ lasted $48 \mathrm{~h}$. Total length of newly hatched larvae (day 0) was $2.32 \pm 0.12 \mathrm{~mm}$. Hatching rate was $88 \%$. Larvae opened the mouth and anus on day $3 \mathrm{AH}$ and began to feed on day 4 after the absorption of the yolk sac. Larvae from all treatments commenced tail flexion by day $16 \mathrm{AH}$. No lordosis was detected in juveniles by day $50 \mathrm{AH}$. On day $20 \mathrm{AH}$, all individuals had a functional swim bladder. By day $23 \mathrm{AH}$, no rotifers were detected in the rearing tanks.

Table 2

Survival and total length of $\mathbf{2 4}$ and 50-days old larvae and fries reared by three different weaning methods. Different letters within a column indicate significant differences between treatments $(P<0.05)$

Supervivencia y largo total de larvas y alevines de 24 y 50 días sometidos a tres estrategias de destete. Las diferentes letras dentro de una misma columna indican diferencias significativas entre tratamientos $(P<0,05)$

\begin{tabular}{ccccc}
\hline \multirow{2}{*}{$\begin{array}{c}\text { Weaning } \\
\text { method }\end{array}$} & \multicolumn{2}{c}{$\begin{array}{c}\text { Survival (\%) } \\
\text { mean } \pm \text { sd }\end{array}$} & \multicolumn{2}{c}{$\begin{array}{c}\text { Total length (mm) } \\
\text { mean } \pm \text { sd }\end{array}$} \\
& 24-day old & 50-day old & 24-day old & 50-day old \\
\hline A & $9.8 \pm 3.3^{\mathrm{a}}$ & $3.2 \pm 2.4^{\mathrm{a}}$ & $6.7 \pm 0.6^{\mathrm{a}}$ & $50.8 \pm 6.9^{\mathrm{a}}$ \\
B & $45.6 \pm 3.6^{\mathrm{b}}$ & $41.8 \pm 4.3^{\mathrm{b}}$ & $7.4 \pm 0.4^{\mathrm{b}}$ & $56.3 \pm 5.1^{\mathrm{b}}$ \\
C & $16.5 \pm 4.2^{\mathrm{c}}$ & - & $5.1 \pm 1.1^{\mathrm{c}}$ & - \\
\hline
\end{tabular}


Best survival rate and growth were found in treatment B (Table 2). The larvae fed Artemia nauplii and inert diet showed a significantly larger total length $(7.4 \pm 0.5 \mathrm{~mm})$ and better survival rate $(45.6 \pm 7.6 \%)$, when compared with the other treatments. Individuals from treatment C, massively died between days 25-30 $\mathrm{AH}$. No food items were detected in the gut of these larvae.

\section{Discussion}

This study demonstrated that the one-step early weaning by co-feeding (treatment B) resulted in a increased survival and growth rate in red porgy larvae. Growth and survival was lower in larvae fed an inert diet alone compared to those fed Artemia or a combination of Artemia and inert diet. Similar results were obtained by Lazo (1999) in red drum larvae (Sciaenops oscellatus).

Stephanou et al. (1995) and Mihelakakis et al. (2001), reported the starting of the weaning phase of red porgy by day 32-33 AH, but no data about survival rate were presented. Kentouri et al. (1995) utilized the traditional three-step larval rearing, starting the weaning phase of red porgy larvae approximately by day $26 \mathrm{AH}$, with a low final survival rate of $6 \%$ (Table 3 ).

Weaning conditions clearly influenced the growth and survival of red porgy. Assimilation of ingested rotifers, or other live feeds, by fish larvae can occur rapidly (Lubzens et al. 1989). Consequently, larvae from all treatments faced similar feeding conditions during the first 20 days of development. The faster larval growth in treatment B showed low individual size variation and high survival rate. High size variation usually occurred in the larvae that apparently experienced adverse growth (Dou et al. 2003).

Traditionally, it has been assumed that the inability of marine fish larvae to grow well with inert diets was a consequence of their low enzymatic activity (Lazo 2000). It has also been suggested that the real cause of the poor growth and low survival of marine fish larvae was directly related to nutritionally unbalanced inert diets (Cahu \& Zambonino-Infante 1997). Although inert diets provide sufficient nutrient in a digestible form, it is more likely that these diets failed to stimulate ingestion (Allen Davis \& Dinis 2002). This may be an
Table 3

\section{Survival rates (\%) of red porgy larvae reported by different authors. DAH = days after hatching}

Tasas de supervivencia (\%) en larvas de besugo señaladas por varios autores. DAH = días después de la eclosión

\begin{tabular}{|c|c|c|c|}
\hline $\begin{array}{l}\text { Survival } \\
\text { rate (\%) }\end{array}$ & $\begin{array}{c}\text { DA } \\
\mathrm{H}\end{array}$ & Culture density & References \\
\hline 6.7 & 8 & - & $\begin{array}{l}\text { Conides \& Glamuzina } \\
\text { (2001) }\end{array}$ \\
\hline 17.7 & 17 & $100-150$ eggs/L & $\begin{array}{l}\text { Hernandez-Cruz et al. } \\
\text { (1999) }\end{array}$ \\
\hline 6.0 & 50 & 50-70 larvae/L & Kentouri et al. (1995) \\
\hline 15.0 & 50 & 1 larva/L & Kentouri et al. (1995) \\
\hline
\end{tabular}

explanation of the lack of food items in the gut of red porgy larvae in treatment C. By co-feeding red porgy larvae with Artemia nauplii and inert diet (treatment B), survival increased significantly and positively correlated with the increase of growth rate. The ingestion of Artemia nauplii may stimulate the ingestion of inert diet and its digestion. Artemia is a good carrier of HUFA as it incorporates them to its body, but it is poor in other nutrients, such as proteins. Consequently, the traditional three-step larval rearing (treatment A) may restrict the incorporation of some essential elements reducing growth rate. Results indicate that co-feeding red porgy larvae with inert and live diets by day 20 is a promising weaning strategy in the hatchery of this species. Adding of inert diet to the feeding strategy in treatment B may supply the necessary elements to promote a good larval development and survival. Further studies will be needed to improve the transferring of these nutrients from live food to red porgy larvae during the hatchery.

\section{Acknowledgments}

We appreciate the helpful cooperation of H. Makinouchi from OFCF. The authors are greatly indebted to Federico Bianca and Andrea López for the supply of rotifers and microalgae, respectively. This work has been financed by the INIDEP and the OFCF in the frame of the Cooperation Agreement signed between both institutions. We also appreciate the careful revision, comments and suggestions of the anonymous referees. 


\section{Literature cited}

Allen Davis D \& MT Dinis. 2002. Marine larval fish production: A nutritional perspective. Aqua Feed International, July-September, pp. 7-11.

Aristizabal EO. (in press). Desove en cautiverio y calidad de los huevos y larvas del besugo, Pagrus pagrus (L.). Serie INIDEP Informes Técnicos 59.

Aristizabal EO. 2003. Bioenergética en el besugo, Pagrus pagrus. Tesis de Doctorado, Facultad de Ciencias Exactas y Naturales, Universidad Nacional de Mar del Plata, Argentina, 145 pp.

Bromley PJ \& BR Howell. 1983. Factors influencing the survival and growth of turbot larvae, Scophthalmus maximum L., during the change from live to compound feeds. Aquaculture 31: 31-40.

Cahu CL \& JL Zambonino-Infante. 1997. Is the digestive capacity of marine fish larvae sufficient for compound diet feeding? Aquaculture International 5: 151-160.

Cañavate JP \& C Fernández-Díaz. 1999. Influence of cofeeding larvae with live and inert diet on weaning the sole Solea senegalensis onto commercial dry feeds. Aquaculture 174: 255-263.

Conides AJ \& B Glamuzina. 2001. Study on early larval development and growth of the red porgy, Pagrus pagrus with emphasis on the mass mortalities observed during this phase. Scientia Marina 65: 193-200.

Cotrina C. 1989. Estudio biológico del besugo (Pagrus pagrus) del Ecosistema Costero Bonaerense. Tesis de Doctorado, Facultad de Ciencias Exactas y Naturales, Universidad de Buenos Aires, Argentina, 161 pp.

Cotrina C \& MB Cousseau. 1977. Informe sobre el muestreo bioestadístico de desembarque de pescado en el puerto de Mar del Plata. Período enero de 1972-diciembre de 1974. Contribuciones del Instituto de Biología Marina, Mar del Plata, $\mathrm{N}^{\circ} 330,34 \mathrm{pp}$.

Dou S, R Masuda, M Tanaka \& K Tsukamoto. 2003. Identification of factors affecting the growth and survival of the settling Japanese flounder larvae, Paralichthys olivaceus. Aquaculture 218: 309-327.

Fernández-Díaz C, E Pascual \& M Yúfera. 1994. Feeding behavior and prey size selection of gilthead seabream, Sparus aurata L., larvae fed on inert and live food. Marine Biology 118: 323-328.
Hernández-Cruz CM, M Salhi, M Bessonat, MS Izquierdo, MM González \& H Fernández-Palacios. 1999. Rearing techniques for red porgy (Pagrus pagrus) during larval development. Aquaculture 179: 489-497.

Kanazawa A, S Koshio \& S Teshima. 1989. Growth and survival of larval red sea bream Pagrus major and Japanese flounder Paralichthys olivaceus fed microbond diets. Journal of the World Aquaculture Society 20(2): 3137.

Kentouri M, M Pavlidis, N Papandroulakis \& P Divanach. 1995. Culture of the red porgy, Pagrus pagrus, in Crete. Present knowledge, problems and perspectives. Workshop on Diversification in Aquaculture, Cyprus, Cahier Options Mediterranee 16: 65-78.

Kolkovski S. 2001. Digestive enzymes in fish larvae and juveniles - implications and applications to formulated diets. Aquaculture 200: 181-201.

Lazo JP. 1999. Development of the digestive system in red drum (Sciaenops oscellatus) larvae. $\mathrm{PhD}$ Thesis, Department of Marine Sciences, The University of Texas at Austin, Texas, USA, $210 \mathrm{pp}$.

Lazo JP. 2000. Conocimiento actual y nuevas perspectivas en el desarrollo de dietas para larvas de peces marinos. En: Cruz-Suárez LE, D Ricque-Marie, M Tapia-Salazar, MA Olivera-Novoa \& R Civera-Cerecedo (eds), Avances en Nutrición Acuícola V. Memorias del V Simposium Internacional de Nutrición Acuícola, 19-22 noviembre, 2000, México, pp. 300-312.

Lubzens E, A Tandler \& G Minkoff. 1989. Rotifers as food in aquaculture. Hydrobiologia 186/187: 387-400.

Mihelakakis A, T Yoshimatsu \& C Tsolkas. 2001. Spawning in captivity and early life history of cultured red porgy, Pagrus pagrus. Aquaculture 199: 333-352.

Munilla-Moran R, JR Stark \& A Barbour. 1990. The role of exogenous enzymes in digestion in cultured turbot larvae (Scophthalmus maximus L.). Aquaculture 88: 337350.

Mylonas CC, M Papadaki \& P Divanach. 2003. Seasonal changes in sperm production and quality in the red porgy Pagrus pagrus (L.). Aquaculture Research 34: 1161-1170.

Person Le Ruyet J, JC Alexandre, L Thebaud \& C Mugnier. 1993. Marine fish larvae feeding: formulated diets or live prey? Journal of the World Aquaculture Society 24: 211-224. 
Roo FJ, J Socorro, MS Izquierdo, MJ Caballero, CM Hernández-Cruz, A Fernández \& H FernándezPalacios. 1999. Development of red porgy Pagrus pagrus visual system in relation with changes in the digestive tract and larval feeding habits. Aquaculture 179: 499-512.

Rosenlund G, J Stoss \& C Talbot. 1997. Co-feeding marine fish larvae with inert and live diets. Aquaculture 155: 183191.

Sargent JR, LA McEvoy \& JG Bell. 1997. Requirements, presentation and sources of polyunsaturated fatty acids in marine fish larval feeds. Aquaculture 155: 117-128.
Sokal RR \& J Rohlf. 1981. Biometry. The Principles and Practice of Statistics in Biological Research, 859 pp. $2^{\text {nd }}$ ed, Freeman, New York.

Stephanou D, G Georgiou \& E Shoukri. 1995. Reproduction and larval rearing of the common sea bream (Pagrus pagrus), an experimental culture. Workshop on Diversification in Aquaculture, Cyprus, Cahier Options Mediterranee 16: 79-87.

Recibido el 5 de abril de 2006 y aceptado el 5 de septiembre de 2006 